\title{
The Impact of Tax Policy on Economic Growth, Income Distribution, and Allocation of Taxes
}

\author{
Robert Lawson \\ Southern Methodist University, rlawson@smu.edu \\ James Gwartney \\ Florida State University
}

Follow this and additional works at: https://scholar.smu.edu/business_law_research

Part of the Taxation Commons

This document is brought to you for free and open access by the Business Law at SMU Scholar. It has been accepted for inclusion in Business Law Research by an authorized administrator of SMU Scholar. For more information, please visit http://digitalrepository.smu.edu. 
THE IMPACT OF TAX POLICY ON ECONOMIC GROWTH, INCOME DISTRIBUTION, AND ALLOCATION OF TAXES

\author{
James Gwartney \\ Professor of Economics and Gus A. Stavros Eminent Scholar Chair \\ Florida State University \\ Robert Lawson \\ Professor of Economics and George H. Moor Chair \\ Capital University
}




\title{
THE IMPACT OF TAX POLICY ON ECONOMIC GROWTH, INCOME DISTRIBUTION, AND ALLOCATION OF TAXES
}

\author{
By James Gwartney and Robert Lawson
}

\section{INTRODUCTION}

There is considerable disagreement about how taxes, especially high marginal tax rates on those with large incomes, influence economic performance and the distribution of income. This paper uses data on marginal tax rates since 1980 for countries that have a personal income tax to analyze this topic. Section II uses economic theory to analyze the linkage between marginal tax rates and economic performance and considers a number of factors that complicate the measurement of that impact. Section III presents country data on the top marginal tax rates imposed during 1980-2002 and illustrates the reduction in the highest marginal rates since 1985. Section IV analyzes the impact of high marginal tax rates on economic growth and Section $\mathrm{V}$ focuses on how reductions in marginal tax rates, particularly the highest rates, influence income inequality and the share of the personal income tax paid by various income groups. The final section summarizes the findings of this study.

\section{MARGINAL TAX RATES AND ECONOMIC PERFORMANCE}

From an economic viewpoint, marginal tax rates are considered particularly important because they affect the incentive of individuals to earn additional income. As marginal tax rates rise, individuals get to keep less and less of their additional earnings. 
High marginal tax rates influence economic performance in at least three major ways. First, high marginal rates discourage work effort. As taxes reduce the amount of additional earnings that one is permitted to keep, individuals tend to work and earn less. People will make this adjustment in various ways. Some, for example those with a working spouse, may drop out of the labor force. Others will respond by working fewer hours per week. Still others will decide to take more lengthy vacations, forgo overtime opportunities, retire earlier, or forget about pursuing that promising but risky business venture. In some cases, high tax rates will even drive highly productive citizens to other countries where taxes are lower. For example, when the incomes of athletes, skilled professionals, and business entrepreneurs are not country dependent, they often re-locate from high to low tax countries.

Second, high marginal tax rates distort price signals and encourage individuals to substitute less-desired but tax-deductible goods for non-deductible ones that are moredesired. Goods and services may be tax-deductible as the result of either the design of the tax structure or because they appear as a legitimate business expense. In both cases, the personal costs of purchasing the deductible items will be lower than both society's cost of supplying the items and the cost of purchasing nondeductible goods of similar price. The higher an individual's effective marginal tax rate, the cheaper the personal cost of the deductible item. This incentive structure will induce persons in high-tax brackets to spend excessively on plush offices, professional conferences held in favorite vacation spots, business entertainment, luxury cars used for business purposes, and numerous other deductible items. Persons in high tax brackets will often purchase such items even when they are valued less than their production costs. Scarce resources are wasted producing 
goods that are not valued as much as other things that could have been produced instead. As a result, living standards will fall short of their potential.

Third, high tax rates will reduce the incentive of people to invest in both physical and human capital. When tax rates are high, foreign investors will look for other places to put their money, and domestic investors will look for investment projects abroad where taxes are lower. High marginal rates will also reduce the incentive to invest in education and skill development. After all, high tax rates mean that investors in human capital, like their physical capital counterparts, are unable to capture a substantial share of the returns from their investment. Furthermore, domestic investors will direct more of their investments into hobby businesses (like collecting antiques, raising horses, or giving golf lessons) that may not earn much money but are enjoyable and have tax-shelter advantages. This too, will divert resources away from projects with higher rates of return but fewer tax-avoidance benefits. Again, scarce capital will be wasted and resources channeled away from their most productive uses.

In summary, theory indicates that high marginal tax rates will reduce the supply of both labor and capital, and adversely affect the efficiency of resource use. These negative side effects are likely to be particularly strong when marginal tax rates are exceedingly high. Thus, one would expect countries with high marginal tax rates to grow less rapidly and fail to realize their full potential. Similarly, one would expect that increases in marginal tax rates would be negatively related with economic growth. If marginal tax rates are already high, the impact of rate increases is likely to be particularly destructive. 
While theory predicts that there will be a negative relationship between marginal tax rates and the growth rate of an economy, it also suggests several factors that will complicate measurement of the linkage. First, there is the difference between the short run and long run response to a change in marginal rates. To the extent that an increase in marginal tax rates reduces the supply of labor and capital, it will tend to slow the growth of real GDP. But, these responses will take time and the short-run response may be a misleading indicator of what will happen in the long run. Clearly, the labor supply response will generally be smaller in the short run than in the long run. For example, most people who have previously trained and developed skills for a career of market work are likely to remain in the labor force even if higher marginal tax rates substantially reduce the return from their prior investment. Thus, the short-run labor supply response to a change in marginal tax rates is likely to be small. This is consistent with the empirical findings. Most studies of this topic estimate that the elasticity of labor supply is between 0.1 and $0.2{ }^{1} \quad$ This implies that higher marginal tax rates that reduced wages by 10 percent would reduce the quantity of labor supplied by between 1 percent and 2 percent.

In the long run, however, the labor supply response will be larger, perhaps substantially larger. ${ }^{2}$ As a result of the high marginal rates, future labor force participants have less incentive to invest and acquire the education and training required for highpaying jobs, particularly if those jobs are stressful and difficult to perform. In contrast, people have more incentive to prepare for jobs that are interesting and provide substantial non pecuniary, and therefore untaxed, benefits. With time, adjustments of this type will tend to reduce the quality and productivity of the labor force by larger and larger 
amounts. But they are likely to take a decade or more and, as a result, a lengthy time period will pass before the full labor supply response will be observed. Thus, when seeking to isolate the impact of changes in marginal tax rates, it is important to analyze their impact on growth over periods of a decade or more.

Second, GDP figures will often fail to register the negative impact of the price distortions accompanying high marginal tax rates. GDP registers the expenditures and costs of the goods and services produced even if that exceeds the value derived by the consumer. If taxpayers purchase deductible items that they value less than their cost because their personal cost is low, the full costs of such items will nonetheless be added to GDP. For example, if a taxpayer in a 60 percent marginal tax bracket purchases a $\$ 50,000$ automobile even though he or she values the car at only $\$ 25,000$, the purchase of the car will nonetheless add $\$ 50,000$ to GDP. Because GDP records the costs of production rather than the value to the consumer, both GDP and its growth rate will understate the adverse side effects of high marginal tax rates.

Third, the linkage between marginal tax rates and GDP growth may also be weakened by the pattern of government expenditures. Several countries impose high marginal tax rates in order to derive revenues that are utilized to subsidize child care services, retirement benefits and payments to persons not working. Suppose that a country increases its marginal tax rates in order to subsidize child care services for working-age parents. While the higher marginal tax rates tend to reduce labor supply, subsidies for childcare services act as an offsetting factor by making it less costly for adults with children to engage in market work. The net effect on labor supply is likely to be small. Further, the policy change will increase the share of childcare services provided 
by the government (and market suppliers) relative to the share supplied within the household sector. Because the former adds to GDP but the latter does not, the higher taxes that subsidize and provide child care services may actually increase income as measured by GDP.

Alternatively, suppose that taxes are increased in order to provide more generous benefits to retirees and/or unemployed workers. The more generous retirement benefits would encourage more workers to retire earlier and the more generous unemployment benefits would lead to more lengthy periods of job search and higher rates of unemployment. Both of these expenditures would tend to reduce the effective supply of labor and thereby reinforce the impact of the higher marginal tax rates. In contrast with the expenditures on childcare services, these expenditures would tend to amplify the negative relationship between higher marginal tax rates and the quantity of labor supplied. Thus, variations in the pattern of expenditures accompanying differences in marginal tax rates will also influence both labor supply and the expected impact on the growth rate of income as measured by real GDP.

The impact of marginal tax rates will be greatest in the highest tax brackets. It is in the high tax brackets where changes in tax rates will exert their largest affects on both labor supply and tax avoidance activities. Furthermore, as the Laffer curve analysis indicates, marginal tax rates can be pushed so high that they will actually reduce the revenues derived from the tax. Obviously, marginal tax rates above the revenue maximum level are highly inefficient. They reduce both aggregate output and the revenue derived by the government. But tax rates near the revenue maximum point are also extremely inefficient. As rates are increased toward the revenue maximum point, the 
higher tax rates will squeeze out substantial amounts of economic activity relative to the additional revenue generated. Thus, measured in terms of lost output, these additional revenues are very costly. Because the most severe side effects of taxes will be exerted by the highest marginal rates, our empirical analysis will focus on these rates.

\section{MARGINAL TAX RATES, 1980-2002}

We have collected data for seventy-seven countries that levied a personal income tax throughout 1980-2002. ${ }^{3}$ As Table 1 shows, there has been a dramatic change in the top marginal tax rate levied by these countries during the last two decades. The average top marginal tax rate in 1980 was 61.3 percent, and the parallel figure in 1985 was only slightly lower. But, the average top rate declined to 48.5 percent in 1990 and to 40.8 percent in 1995. Thus, the average top marginal tax rate among the seventy-seven countries declined by almost 20 percentage points between 1985 and 1995. And the trend has continued; the average top rate receded to 37.1 percent in 2002. The median top marginal tax rate followed a similar path.

High marginal tax rates will exert less impact on economic performance if they apply only at extremely high levels of income. In order to consider the potential importance of this factor, the rating matrix used in the Economic Freedom of the World (EFW) index was used to adjust for the income level at which the top rate initially applies. ${ }^{4}$ This matrix assigns ratings on a zero-to-ten scale based on both the top marginal tax rate and the level of income at which it initially takes affect. Countries with the lowest marginal tax rates are assigned the highest ratings, while countries with high top 
marginal tax rates that take affect at low levels of income are rated the lowest. This matrix showing the zero-to-ten ratings for the various top marginal tax rate and income level categories is presented in Appendix Table A1. Appendix Table A2 presents both the top marginal income tax rate and the rating for the 77 countries of our study for various years during 1980-2002.

While many countries have reduced their top marginal rates substantially, some countries have maintained persistently high rates throughout the 1980s and 1990s. Table 2 presents the list of 14 countries with top marginal income tax rates of 50 percent or more throughout 1980-1995. Italy, Sweden, Belgium, Denmark, and Japan head this list of persistently high tax countries. On average, the top marginal tax rate of these countries exceeded 60 percent during 1980-1995.

In some countries, payroll taxes are levied either at all levels of income or at income levels that are well above the tax bracket where the top marginal rate begins to apply. When this is the case, the payroll tax rate will increase the top marginal rate applicable to earnings. In some cases, the increase in the top marginal rate is substantial. Since 1990, we have been able to calculate a top marginal tax rate that includes the payroll tax as well as the personal income tax. These figures are included in Table A3 of the Appendix.

Table 3 indicates countries during 1990-2000 with high and low marginal tax rates based on the inclusion of both the personal income and payroll tax. Once the payroll tax was integrated into the calculation, there were nine countries with top marginal tax rates of 60 percent or more throughout the $1990-2000$ period. At the other 
end of the spectrum, there were 13 countries with top marginal rates (including the payroll tax) of 40 percent or less throughout the 1990 s.

\section{TOP MARGINAL TAX RATES AND ECONOMIC GROWTH}

The dramatic changes in the highest marginal tax rates during the last two decades provide something like a natural experiment. The top marginal rates in some countries remained at high levels — 50 percent or more - throughout the 1980s and most of the 1990s. Other countries had top marginal rates that were substantially lower in the 1990s than the 1980s. Was there any difference in the economic performance of the two groups? How did the growth rates of the countries that sharply reduced their top rates compare with the growth of those that maintained high rates? This section will address these questions.

\section{A. Economic Growth of the High Versus Low Tax Countries: 1990s}

How did the high tax countries during the 1990s perform relative to those with low tax rates? As Table 4 shows, the nine countries with top marginal tax rates (including the payroll tax) of 60 percent or more during the 1990s grew at an average annual rate of 0.38 percent during 1990-2002, down from 1.35 percent during the 1980 s. Denmark's growth rate of 1.86 percent was the highest among those in the high-tax group. Eight of the nine high tax countries, again Denmark was the exception, grew more slowly during 1990-2002 than during the 1980s.

On the other hand, the 13 countries with a top marginal income tax rate of 40 percent or less (including the payroll tax) grew at an average annual rate of 2.08 percent 
during 1990-2002, up from 1.58 percent during the 1980s. Thus, the average growth rate of the low-tax group during 1990-2002 was 1.7 percentage points higher than the average for the high tax group. Further, while the average growth rate of the high-tax countries was approximately 1 percentage point lower in 1990-2002 than in the 1980s, the growth rate of the low tax group was a half of a percentage point higher during the latter period.

Table 5 uses regression analysis to investigate the linkage between the level of tax rates and growth for all of the 77 countries. The dependent variable is the growth rate of per capita GDP during 1990-2002. Growth of per capita GDP during the 1980s is incorporated as an independent control variable. This variable should capture many of the important institutional and cultural factors that influence cross-country differences in long-term growth. Put another way, factors like political stability, an even-handed legal system, a well-educated and highly skilled labor force, and sound monetary, financial and trade institutions that resulted in strong growth during the 1980s are also likely to exert a positive impact on growth during the 1990s. Correspondingly, institutional and cultural factors that resulted in weak growth during the 1980s will also tend to retard growth during the 1990s. ${ }^{5}$ The findings are supportive of this view. The coefficient for the growth rate during the 1980s was positive and significant in a statistical sense (t-ratios near 7.0 in all of the regression equations).

The average of the top marginal tax rate during 1990-1995 is also incorporated as an independent variable. In Equation 1, the marginal tax rate variable has a negative sign. ${ }^{6}$ This indicates that after controlling for growth during the 1980s, countries with higher top marginal tax rates during the 1990s grew less rapidly than those with lower top rates. In Equation 2, per capita GDP at the beginning of the period (i.e. 1990) is added to 
the model. After inclusion of the initial per capita income variable, the marginal tax rate variable drops slightly outside of the usual acceptable range for statistical significance.

The models represented by Equations 3 and 4 are parallel to those of Equations 1 and 2 except that the EFW top tax rating, which also incorporates the income level at which the top marginal rate applies, is used rather than the marginal tax rate itself. The rating variable is a more refined measure, and because the higher ratings are indicative of lower marginal tax rates (and initial application of high marginal rates at higher levels of income), the expected sign of this variable is positive. As Equations 3 and 4 show, the EFW marginal tax rating coefficient is positive. A one point increase in the rating variable scale is associated with a five percentage point increase in the marginal tax rate, holding constant the income level at which the top rate initially applies. (See Appendix, Table A1). Thus, the 0.15 coefficient on the rating variable in Equations 3 and 4 indicates that a ten percentage point lower top marginal tax rate is associated with approximately three-tenths of a percentage point change in long-term growth. These findings suggest that countries with persistently high marginal tax rates pay a price in terms of a slower rate of long-term growth.

\section{B. Economic Growth and Changes in Top Marginal Tax Rates.}

As Table 1 shows, the average top marginal income tax rate among the 77 countries declined sharply between 1985 and 1995 . This reflects the fact that many countries made substantial reductions in their top rate during this period. Table 6 provides a list of the countries that reduced their top marginal rate by 25 percentage points or more between 1985 and 1995. This is a diverse list that includes countries from all regions of the world. It includes low-income developing countries such as Tanzania, Zambia, and 
Bangladesh as well as high-income industrial countries like New Zealand and Sweden. In some cases, the economies of the tax cutters had high growth rates prior to 1985. Botswana and Thailand provide examples. In other cases, like Peru, Ecuador, and Ghana, the top rates were slashed against a backdrop of dismal economic performance.

If marginal tax rates impact growth, countries that reduce their marginal rates should grow more rapidly than those that do not. Table 7 uses regression analysis to investigate this issue. Once again, the dependent variable is the annual growth rate of per capita real GDP during 1990-2002. As in Table 5, the growth rate of real GDP during the 1980s is incorporated as an independent variable in order to adjust for cross-country differences in institutional and cultural factors that influence long-term growth. As expected, this variable is significant and positively related to growth during 1990-2002.

In Equations 1 through 3, the change in the top marginal tax rate (measured in percentage points) between 1985 and 1990 and between 1990 and 1995 is incorporated as a measure of change in the top marginal tax rate. Equation 1 includes only the two change-in-tax-rate variables along with the growth rate during the 1980's in the model. Equation 2 adds the per capita GDP at the beginning of the period (1990). Equation 3 adds the initial top marginal tax rate (1985). The coefficients for both of the changes in marginal tax rate variables were negative, and the impact of the change in the top marginal rate between 1985 and 1990 was quite similar to the impact of the change in the top rate between 1990 and 1995. This is consistent with the view that a reduction in the highest marginal rates will influence growth over a lengthy time period. Equation 3 indicates that, holding the other variables of the model constant, a 10 percentage point reduction in the top marginal rate is associated with approximately a 0.5 percentage point 
increase in long-term growth. The R-squared implies that the model represented by Equation 3 accounts for 40 percent of the variation in the growth rate of GDP among the 77 countries during 1990-2002.

Equations 4, 5, and 6 are similar to those of Equations 1 through 3 except that the marginal tax EFW rating is substituted for the top marginal rates in the case of both the change variables and the initial (1985) top marginal tax rate. In the more comprehensive model (Equation 6), a one-unit increase in the rating between 1985 and 1990 enhances growth during the 1990 s by 0.241 percentage points. A unit increase in the rating between 1990 and 1995 is associated with a 0.304 percentage point increase in growth during 1990-2002. This implies that a 10 percentage point reduction in marginal tax rates increases the annual growth rate of an economy by approximately 0.5 to 0.6 percentage points. The model represented by Equation 6 accounts for 43.7 percent of the GDP per capita variation among the 77 countries.

These findings are consistent with the view that reductions in marginal tax rates, particularly rates that are exceedingly high, influence the growth rate of an economy. Of course, they are subject to the usual limitations accompanying cross-country regression analysis, particularly bias emanating from an inability to control for other factors influencing growth. To the extent that countries reducing their marginal rates between 1985 and 1995 were more likely to adopt other growth enhancing reforms than the nontax cutters, the estimates presented here will overstate the impact of the changes in the top tax rates. But, there are also biases in the opposite direction. As we discussed above, real GDP (and its growth rate) will fail to register several of the negative side effects accompanying high marginal tax rates. This is particularly true of those associated with 
price distortions and tax avoidance activities. Because the estimates presented here use the growth figures for real GDP as a measure of the negative side effects of high marginal rates, they will fail to capture fully the distorting effects of high marginal rates. This factor means that the estimates presented here will understate the negative impact of the high marginal rates.

\section{MARGINAL TAX RATES, INCOME INEQUALITY, AND TAX PAYMENTS}

\section{A. Theoretical Considerations}

Most tax cuts are more or less across-the-board because, from a political viewpoint, the lower rates will have to be cut in order to make the cuts in the top brackets politically feasible. Thus, it is important to understand that across-the-board cuts in marginal tax rates will have different incentive effects up and down the income distribution. Suppose that a government with progressive income tax rates ranging from a low of 15 percent to a high of 75 percent reduced tax rates across the board by onethird. The top tax rate would then fall from 75 percent to 50 percent. After the tax cut, taxpayers in the highest tax bracket who earn an additional $\$ 100$ would get to keep $\$ 50$ rather than only $\$ 25$, a 100 percent increase in the incentive to earn additional income. Predictably, these taxpayers will have a strong incentive to earn more taxable income after the rate reduction, and the revenues collected from them will decline by substantially less than a third. In fact, given the huge increase in their incentive to earn, the revenues collected from taxpayers confronting such high marginal rates may actually increase, an outcome suggested by the Laffer Curve. 
Meanwhile, the same 33 percent rate reduction will only cut the bottom tax rate from 15 percent to 10 percent. In this range, the tax cut means that an additional $\$ 100$ in gross pay increases take-home pay by $\$ 90$ instead of $\$ 85$, a 5.9 percent increase in the incentive to earn additional income. Because cutting the 15 percent rate to 10 percent exerts only a small effect on the incentive to earn in the lower tax (and lower income) brackets, the incomes of persons in these marginal tax brackets will be largely unchanged. Thus, the taxable income base of persons in the lower tax brackets will not be altered much by the tax cut. Therefore, in contrast with the situation in high tax brackets, tax revenue will decline by almost the same percent as tax rates in the lowest tax brackets.

The bottom line is that when all rates are cut by approximately the same percentage, the increase in the incentive to earn will be greatest in the upper tax (and income) brackets. There will be two major side effects of this change in incentive structure. First, income inequality will increase. Predictably, the incomes of those in the high tax brackets will expand by a larger amount than those in the lower tax brackets. Some of this increase in income will reflect a decline in tax avoidance activities and some of it will reflect the substitution of work for leisure. Both will show up as an increase in the observed income of persons in the upper tax and upper income brackets.

Second, a larger share of the income tax will be paid by high-income taxpayers. Because the tax cut will increase the incentive to earn more in high than low income brackets, taxable income will expand more and the taxes paid will decline less in the upper income brackets. When the top marginal rates are extremely high, taxes collected 
from the high-income taxpayers may even increase. But even if this is not the case, a larger share of the income tax will still be collected from those with high incomes.

\section{B. Marginal Tax Rates and the Distribution of Income: Empirical Evidence}

If our analysis is correct, even across-the-board rate reductions will lead to an increase in income inequality. If the rate reductions are greater in the high tax brackets than in the lower brackets, the expected increase in income inequality will be even greater. Thus, countries that reduce their highest rates by substantial amounts should experience increases in income inequality. Reliable data on the distribution of income are unavailable for many of the 77 countries that comprise the central data base of this study. Furthermore, even when income distribution data are available, there are often serious problems with comparability across countries. ${ }^{7}$ Therefore, we are unable to use regression analysis to undertake a detailed statistical analysis of this issue.

Comparable data are available for the United States both before and after the major personal income tax cuts that have occurred since 1960. Data are also available for other countries, including several that reduced their rates substantially during a 19851995 period. These data can be compared with data from countries that have persistently maintained high marginal tax rates. These comparisons will shed light on the relationship between high marginal tax rates and income inequality.

We will begin by looking at the data for the United States. The personal income tax is the largest single source of revenue for the federal government of the United States. The rate structure of the income tax is progressive; taxpayers with larger incomes face higher tax rates. However, the structure of the rates has changed substantially since 1960. In the early 1960s, there were 24 marginal tax brackets ranging from a low of 20 percent 
to a high of 91 percent. The Kennedy-Johnson tax cut was roughly an across the board proportional rate reduction. The 91 percent top rate was sliced to 70 percent and the 20 percent rate was cut to 14 percent. In 1981, the first tax cut of the Reagan years reduced the top rate from 70 percent to 50 percent and the lowest rate was cut from 14 percent to 10 percent. The second Reagan tax cut sliced the top marginal rate to approximately 30 percent beginning in 1988. The top rate was increased to 33 percent in 1991 and two years later it was increased again to 39.6 percent, but the tax reductions during the administration of George W. Bush rolled the top rate back to 35 percent. Thus, since the late 1980s, Americans with the highest incomes have paid sharply lower top marginal tax rates -- rates in the 30 to 40 percent range compared to top rates of 91 percent in the early 1960s and 70 percent prior to 1981.

What has happened to the distribution of income in the United States? Table 8 provides income distribution data for the U.S. since 1970 and distributional data after taxes (and after taxes and transfers) since 1980. These data highlight two important points. First, taxes and transfers reduce the degree of income inequality. In 2001, the before-tax income share of the top quintile was approximately 14 times that of the bottom quintile. After taxes, the ratio of the income share of the top to bottom quintile was approximately ten.

Second, income inequality in the United States has increased and most of that increase has taken place since 1980. Between 1970 and 1980, there was little change in the before tax distribution of income. In fact, the income share of the bottom quintile rose slightly (from 4.1 percent in 1970 to 4.3 percent in 1980), while the share of the top 5 percent of earners declined (from 16.6 percent to 15.8 percent) during the decade. Since 
1980, however, the situation has been dramatically different. The income share of the bottom quintile fell from 4.3 percent in 1980 to 3.5 percent in 2001 . Over the same time period, the income share of the top quintile of earners rose from 43.7 percent to 50.1 percent, an increase of 6.4 percentage points. Furthermore, the increase in the income share of the top group was entirely the result of the higher incomes registered by the top 5 percent of earners. Between 1980 and 2001, the income share of the top 5 percent rose from 15.8 percent to 22.4 percent, an increase of 6.6 percentage points. This increase more than accounts for the larger income share of the top quintile.

The changes in the distribution of income after taxes and after taxes and transfers followed a similar path. In both cases, the income share of the bottom quintile declined during the 1980s and 1990s, and the share of the top quintile rose during both decades. Again, the growth of income among the top 5 percent of earners accounted for almost all of the increase in the after-tax income share of the top quintile. (Note: data on the income share of the top 5 percent after taxes and transfers were unavailable.)

The increase in income inequality in the U.S. may have other contributing causes. Other researchers have argued that increased trade openness and/or demographic changes, particularly the increase in the number of both single-parent and duel-earner households, have contributed to the increase in inequality. ${ }^{8}$ However, both the timing and structure of the increase in income inequality indicate that reductions in the highest marginal tax rates played an important role. The major increases in inequality began with the sharp reductions in the top marginal rates during the 1980s. Moreover, almost all of the abnormally large increases in income were registered at the very top of the income 
distribution, precisely the place where the incentive effects of rate reductions are the strongest.

Table 9 presents data on the share of household income derived by the top and bottom quintiles in the 1980s and the 1990s-2000s. These figures are presented for (1) countries with persistently low (40 percent or less) top marginal tax rates during the 1990s and (2) countries with persistently high (50 percent or more) top rates during the 1980s and 1990s. ${ }^{9}$ Many of the countries with low top marginal rates during the 1990s reduced their top rates substantially between 1985 and 1995. Therefore, to a large degree, the persistently low tax group is comprised of countries with substantially lower tax rates in the late 1990s than in the early 1980s.

Two things stand out with regard to the pattern of the data in Table 9. First, the income inequality of the countries in the persistently low tax category is greater than for those in the persistently high tax group. In the late 1990s, the income share of the top quintile of earners was 43 percent or more in all of the countries in the low top marginal rate group. In contrast, the income share of the top quintile was between 35 percent and 41 percent for all of the countries in the high tax group.

Second, the general trend appears to be toward more income inequality in the low tax countries but less inequality in countries with high top marginal rates. Income inequality rose in five of the nine low tax countries, while the other four experienced no significant change. In contrast, five of the nine high tax countries registered a reduction in income inequality during the period, and there was no discernible change in three others. An increase in income inequality was observed in only one (Belgium) of the countries in the high tax group. 
From our perspective, the figures for New Zealand and the United Kingdom are particularly interesting. Among the high income industrial countries, these two countries (along with the United States) made the largest tax cuts during the 1980s. New Zealand reduced its top rate from 66 percent in 1985 to 33 percent in 1990. In the United Kingdom, the top marginal rate was reduced from 83 percent in 1980 to 60 percent in 1985 and 40 percent in 1990, and the lower rate has been maintained ever since. As Table 9 shows, the income share derived by the highest quintile of earners increased in both countries. In New Zealand, the income share of the top quintile rose from 40.6 percent in the early 1980s to 43.8 percent in the late 1990s. In the UK, the share of the top quintile jumped from 41.4 percent in the 1980 s to 44.0 percent in the late 1990 s. Like the figures for the U.S., the income distribution data for New Zealand and the United Kingdom indicate that substantial reductions in the highest marginal rates will lead to rapid income growth in the upper income brackets and an increase in the observed income inequality.

One final point about the empirical linkage between lower top tax rates and income inequality: Comparisons of the before and after rate reductions will tend to overstate the change in economic inequality. To some extent, the empirical data reflect the fact that the rate reductions increase the visibility of the income of the highest earners. High tax rates encourage tax avoidance activities that tend to conceal income, broadly defined to include leisure, pleasurable activities, and ability to purchase many goods at a low personal cost. For example, when tax rates are high, those confronting the high rates take more of their "income" in the form of low-cost luxury offices and automobiles, business related vacations in exotic places, pleasurable hobby business activities, and 
similar benefits that conceal their true income. As lower rates make these activities less profitable, those with high incomes shift away from such activities. As they do so, their money income increases and their overall income becomes more visible. In turn, this makes it look like their overall income has increased by a larger amount than is really the case.

\section{Changes in marginal tax rates and the taxes paid by those with high incomes}

As we previously discussed, changes in the incentive structure indicate that a roughly proportional reduction in tax rates will increase both income levels and the share of taxes collected from high-income taxpayers. Because the income base will be more responsive in the upper income brackets, the share of taxes collected from those with high incomes may even increase if their rates are reduced more than proportionally.

Table 10 provides data related to this proposition for the United States. The share of the personal income tax collected from those with high incomes is indicated for various periods from 1963, when the top federal rate was 91 percent, through 1994-2001, when the top federal rate was 39.6 percent. These data show that the share of the personal income tax paid by high income Americans has increased substantially since 1963, and the increase has been particularly sharp since 1980 . The top 1 percent of earners paid 33.4 percent of the personal income tax during 1994-2001, up from 19.1 percent in 1980 and 18.3 percent in 1963 . The top 10 percent of income recipients paid 63.7 percent of the personal income tax during 1994-2001, compared to 49.3 percent in 1980 and 47 percent in 1963. At the same time, the share of the personal income tax paid by the bottom half of the income recipients has steadily fallen from 10.4 percent of the total in 1963 to 7.0 percent in 1980 and just 4.3 percent during $1994-2001 .^{10}$ 
How did the sharp top rate reductions of the 1980s affect the share of taxes collected from high income taxpayers? When the top marginal rates were in the 30 to 33 percent range during 1987-1993, the share of the federal income tax collected from the top one percent of earners rose to 26.3 percent, up from 19.1 percent in 1980 and 18.3 percent in 1963. During 1994-2001, the top one percent paid 33.4 percent of the personal income tax even though the top marginal rate remained at less than 40 percent throughout the period. Furthermore, the personal income taxes collected at the federal level rose to almost nine percent of GDP during 1994-2001, higher than for any of the earlier periods.

Table 11 presents the share of income taxes collected from high income recipients before and after major cuts in the top marginal rates for New Zealand and the United Kingdom, the two other high-income countries that have substantially reduced their top marginal rates. The pattern for both countries is similar to that of the United States. As the top marginal rate in both countries was reduced from more than 60 percent in the early 1980 s to 40 percent or less during the 1990 s, the share of income taxes collected from those with high incomes increased. In New Zealand, the top five percent of earners paid 29 percent of the personal income tax in 1998, compared to 25.1 percent in 1981. The top one percent paid 12.8 percent of the personal income tax in 1998, up from 9.5 percent in 1981. In the United Kingdom, the shift of the tax burden toward those with high incomes was even more dramatic. In 1999, the top 10 percent of earners paid 50 percent of the personal income tax in the UK, up from 35 percent in 1980. Correspondingly, the share paid by the top one percent of income recipients jumped from 11 percent in 1980 to 20 percent in 1999. At the same time, the share of the income tax paid by the bottom half of the income distribution declined substantially. 
The figures for the United States, New Zealand, and the United Kingdom indicate that high marginal tax rates, rates of 50 percent or more for example, will shrink the tax base in the upper income brackets and reduce the tax revenue collected from those with high incomes. Further, as analysis of the incentive effects suggests, the income base in high tax brackets will be highly responsive to rate reductions. Exceedingly high marginal rates can be reduced with little or no loss of revenue. In fact, in extreme cases, more revenue may be collected at the lower rates. Perhaps policymakers, at least in these three countries, have found a way to soak the rich: keep their marginal tax rates relatively modest, 40 percent or less.

\section{CONCLUSION}

Our findings indicate that high marginal tax rates, particularly rates of 50 percent or more, exert an adverse impact on long-term economic growth. We estimate that a 10 percentage point reduction in a country's top marginal tax rate will enhance the country's long-term annual growth rate of real GDP by approximately one-half of a percentage point (see Table 7).

Economic theory indicates that the incentive effects of a proportional reduction in marginal tax rates will be greater in the upper income brackets. Therefore, even an across-the-board rate cut will result in larger income increases among those with the highest income levels. Thus, reductions in high marginal tax rates will tend to increase observed income inequality. Our findings are supportive of this view. The income share of the highest group of earners tended to increase following major reductions in the highest marginal tax rates. See Tables 8 and 9. 
However, because of the stronger incentive effects accompanying reductions in the highest marginal rates, across the board tax reductions will tend to increase the share of taxes paid by those with the highest incomes. The experience of the United States is consistent with this view. Compared to the situation in 1980, when the top marginal tax bracket was 70 percent, the share of the personal income tax paid by those with high incomes (top five percent for example) has been substantially greater in the United States since 1987, even though the top federal income tax rate has been less than 40 percent throughout the latter period. The experience of New Zealand and the United Kingdom, the other two high-income countries that dramatically reduced their highest marginal tax rates in the 1980s, is also supportive of this view. In both cases, the share of the personal income tax paid by those with the highest incomes increased following the lowering of the top rates.

In brief, our findings indicate that high marginal tax rates, rates of 50 percent and above for example, retard economic growth. Lowering these rates will increase income inequality, but it will also increase the share of the personal income tax collected from those with the highest incomes. 


\section{ENDNOTES}

${ }^{1}$ See Thomas MaCurdy, David Green, and Harry Paarsch, "Assessing Empirical Approaches for Analyzing Taxes and Labor Supply," Journal of Human Resources 25 (Summer 1990): 415-490; Robert Triest, "The Effects of Income Tax Deductions on Labor Supply When Deductions are Endogenous," Review of Economics and Statistics 74 (January 1992): 91-99; and Thomas J. Kniesner and James P. Zilak, The Effects of Recent Tax Reforms on Labor Supply, Washington D.C.: American Enterprise Institute, 1998.

${ }^{2}$ The recent work of Edward Prescott, the 2004 Nobel Prize winner, indicates that the long-run negative impact of higher tax rates on labor supply is substantially greater than the short-run estimates. Prescott uses marginal tax differences between France and the United States to derive estimates for the labor supply response over lengthy time periods. He finds that differences in marginal tax rates between France and the United States explain nearly all of the 30 percent short-fall of labor inputs in France relative to the United States. Prescott concludes,

I find it remarkable that virtually all of the large difference in labor supply between France and the United States is due to differences in tax systems. I expected institutional constraints on the operation of labor markets and the nature of the unemployment benefit system to be more important. I was surprised that the welfare gain from reducing the intratemporal tax wedge is so large.(p. 9)

See Edward C. Prescott, "Richard T. Ely Lecture: Prosperity and Depression." American Economic Review, Papers and Proceedings 92, no. 2, (May 2002): 1-15.

${ }^{3}$ The original source of the marginal tax rate data is Price Waterhouse, Individual Taxes: A Worldwide Summary, (various issues). The top marginal tax rates reported here include rates that apply at the subnational level if applicable.

${ }^{4}$ James Gwartney and Robert Lawson. Economic Freedom of the World, 2004 Annual Report (Vancouver, BC: Fraser Institute, 2004). 
${ }^{5}$ Other researchers have used similar techniques in an effort to hold other things constant. For example, when analyzing the impact of changes in the top state income tax rates on income growth, Holcombe and Lacombe compared the growth of per capita income in counties on state borders with income growth in adjacent counties across the state border. This border-matching technique made it possible for them to hold constant many factors such as climate, culture, and proximity to markets that might also influence the growth of income. Their findings indicate that over the 30 year period from 1960 to 1990, states that raised their top income tax rates more than their neighbors had slower income growth and, on average, a 3.4 percent reduction in per capita income. See Randall G. Holcombe and Donald J. Lacombe, "The Effect of State Income Taxation on Per Capita Income Growth” Public Finance Review 32, no. 3 (May 2004): 292312.

${ }^{6}$ Unless otherwise specified, all results reported are "statistically significant" at the 90 percent level of confidence.

${ }^{7}$ Several factors reduce the comparability of income distribution data across countries and time periods. Sometimes the underlying figures are based on income and in other cases they are based on consumption expenditures. Sometimes the income figures are for households and in other cases they are for individuals. Sometimes the figures are derived from national samples, while in other instances they only reflect figures for urban (or rural) dwellers. Some data are after-tax and some are before tax. Thus, extreme care must be exercised in this area.

${ }^{8}$ For information on the linkage between trade openness and income inequality, see Gary Burtless, "International Trade and the Rise in Earnings Inequality," Journal of Economic Literature (June 1995): 800-816; and Symposium on "Income Inequality and Trade," Journal of Economic Perspectives (Summer 1995).

${ }^{9}$ All countries in these two categories for which comparable household income distribution data could be attained are included here. 
${ }^{10}$ In addition to reducing the highest marginal tax rates, the tax reforms of the 1980 s also increased both the standard deduction and personal exemption allowances by substantial amounts. This means that Americans are now able to earn more income before they face any tax liability. Like an across-the-board rate reduction, this structural change shifts the tax liability away from those with lower incomes and toward those with higher incomes. It completely eliminates the tax liability for many. In 2001, for example, 30 percent (approximately 40 million returns) of those filing an income tax return either had zero tax liability or actually received funds from the IRS as the result of the Earned Income Tax Credit, a program that provides a subsidy to the working poor. The tax share data of Table 10 reflect only tax liability; they do not include income transfers resulting from tax credits. If these credits were included, the net taxes paid by the bottom 50 percent of earners would be even smaller than the figures of Table 10 since 1975 when the Earned Income Tax Credit was adopted. 
Table 1: Average and Median Top Marginal Tax Rates, 1980-2002

$\begin{array}{lccc}\text { 1980* } & \begin{array}{c}\text { Average } \\ \text { Tax Rate }\end{array} & & \begin{array}{c}\text { Median } \\ \text { Tax Rate }\end{array} \\ \mathbf{1 9 8 0} & 61.3 & & 60 \\ 1985 & 59.2 & & 60 \\ 1990 & 48.5 & & 50 \\ 1995 & 40.8 & & 40 \\ 2000 & 38.6 & 39 \\ 2002 & 37.1 & 35\end{array}$

* The requisite data for 1980 were not available for all 77 countries. 1980 data area based on 68 observations.

Source:

Authors' calculations. See Table A2. 
Table 2: Countries with Persistently High Tax Rates, 1980-1995

Countries with top marginal tax rates in excess of 50 percent in all years between 1980 and 1995

Italy

Sweden

Belgium

Denmark

Japan

Cameroon

Netherlands

Finland

Congo, Dem.

Germany

Egypt

Spain

Turkey

France

Austria

Kenya

Source:

Authors' calculations. See Table A2. 
Table 3: Countries with Persistently High and Persistently Low Top Marginal Tax Rates in the 1990s

Countries with top marginal tax rates in excess of 60 percent (including the payroll tax) in all years between 1990 and 2000

\section{Austria}

Belgium

Cameroon

Congo, D. R.

Denmark

Finland

France

Israel

Sweden

\author{
Countries with top \\ marginal tax rates less \\ than $\mathbf{4 0}$ percent (including \\ the payroll tax) in all years \\ between 1990 and 2000 \\ Bangladesh \\ Costa Rica \\ Ecuador \\ Guatemala \\ Hong Kong \\ Indonesia \\ Jamaica \\ Mauritius \\ New Zealand \\ Philippines \\ Singapore \\ Trinidad/Tob. \\ United Kingdom
}

\section{Source:}

Authors' calculations. See Table A3. 
Table 4: Growth Rates of High and Low Top Marginal Tax Rate Countries

\begin{tabular}{|c|c|c|c|c|c|}
\hline & $\begin{array}{l}\text { Countries with } t \\
\text { rates in excess } \\
\text { (including the } p \\
\text { years between } 1\end{array}$ & $\begin{array}{l}\text { ginal tax } \\
\text { rcent } \\
x \text { ) in all } \\
\text { d } 2000\end{array}$ & & $\begin{array}{l}\text { Countries with } \\
\text { tax rates less th } \\
\text { (including the p } \\
\text { years between }\end{array}$ & $\begin{array}{l}\text { ginal } \\
\text { ercent } \\
\text { ax) in all } \\
\text { d } 2000\end{array}$ \\
\hline & Real GDP Per C & rowth & & Real GDP Per C & rowth \\
\hline & $1980-90$ & $1990-02$ & & $1980-90$ & 1990-02 \\
\hline Austria & $2.15 \%$ & $1.79 \%$ & Bangladesh & $1.13 \%$ & $2.99 \%$ \\
\hline Belgium & $1.89 \%$ & $1.61 \%$ & Costa Rica & $-0.50 \%$ & $2.45 \%$ \\
\hline Cameroon & $0.41 \%$ & $-0.59 \%$ & Ecuador & $-0.51 \%$ & $0.34 \%$ \\
\hline Congo, D. R. & $-2.02 \%$ & $-7.16 \%$ & Guatemala & $-1.61 \%$ & $1.12 \%$ \\
\hline Denmark & $1.54 \%$ & $1.86 \%$ & Hong Kong & $5.08 \%$ & $2.50 \%$ \\
\hline Finland & $2.67 \%$ & $1.53 \%$ & Indonesia & $4.44 \%$ & $2.62 \%$ \\
\hline France & $1.94 \%$ & $1.43 \%$ & Jamaica & $1.36 \%$ & $0.08 \%$ \\
\hline Israel & $1.74 \%$ & $1.43 \%$ & Mauritius & $4.89 \%$ & $4.06 \%$ \\
\hline Sweden & $1.87 \%$ & $1.52 \%$ & New Zealand & $0.84 \%$ & $1.88 \%$ \\
\hline Average & $1.35 \%$ & $0.38 \%$ & Philippines & $-0.72 \%$ & $0.86 \%$ \\
\hline & & & Singapore & $4.90 \%$ & $3.57 \%$ \\
\hline & & & Trinidad/Tobago & $-1.19 \%$ & $2.53 \%$ \\
\hline & & & United Kingdom & $2.45 \%$ & $2.02 \%$ \\
\hline & & & Average & $1.58 \%$ & $2.08 \%$ \\
\hline
\end{tabular}

Source:

World Bank. 2004 World Development Indicators. 
Table 5: The Impact of Top Marginal Tax Rates on Economic Growth

Dependent Variable: GDP per capita growth rate, 1990-2002

(t-statistics in parentheses)

Independent

Variable

(3)

(4)

Intercept

2.172

2.183

0.227

0.299

GDP per capita growth rate, 1980-90

$\begin{array}{llll}0.516 & 0.522 & 0.511 & 0.517 \\ (7.04) & (6.82) & (7.08) & (6.84)\end{array}$

$(7.04) \quad(6.82) \quad(7.08) \quad(6.84)$

GDP per capita, 1990 (ppp US\$1000)

$\begin{array}{ll}-0.007 & -0.007 \\ (-0.28) & (-0.28)\end{array}$

$(-0.28)$

Top marginal tax rate, Average 1990-95

$\begin{array}{ll}-0.027 & -0.026\end{array}$

(1.75) (1.64)

Top marginal tax rate (EFW Rating), Average 1990-95

$\begin{array}{ll}0.155 & 0.151 \\ (2.08) & (1.99)\end{array}$

Adjusted R-Squared

Number of Observations

$\begin{array}{rrrr}38.6 & 37.9 & 39.6 & 38.9 \\ 77 & 77 & 77 & 77\end{array}$


Table 6: Countries that Cut Top Marginal Tax Rates the Most Between 1985 and 1995

\section{Countries Reducing Top}

Marginal Tax Rates by More

than 25 Percentage Points

between 1985 and 1995.

Tanzania

Dominican Rep.

Zambia

Morocco

Uganda

Iran

Bangladesh

Peru

Ecuador

Jamaica

New Zealand

Argentina

Malta

Paraguay

Sweden

Portugal

Thailand

Panama

Botswana

Brazil

Costa Rica

Ghana

Philippines

Source:

Authors' calculations. See Table A2. 
Table 7: The Impact of Changes in Top Marginal Tax Rates on Economic Growth

Dependent Variable: GDP per capita growth rate, 1990-2002

(t-statistics in parentheses)

Independent

Variable

(1)

(2)

(3)

(4)

(5)

(6)

Intercept

0.332

0.361

1.432

0.284

$0.240 \quad-0.350$

GDP per capita growth rate, $1980-90$

0.531

(7.23)

0.533

0.537

$\begin{array}{lll}0.532 & 0.528 & 0.523\end{array}$

GDP per capita, 1990 (ppp US\$1000)

$0.003 \quad 0.008$

$(0.12) \quad(0.29)$

$0.005 \quad 0.014$

(0.19) (0.55)

Top marginal tax rate, 1985

$-0.024$

(1.47)

Top marginal tax rate (EFW Rating), 1985

0.133

(1.63)

Change in Top marginal tax rate from 1985 to 1990

$\begin{array}{rrr}-0.034 & -0.034 & -0.049 \\ (1.84) & (1.83) & (2.33) \\ & & \\ -0.034 & -0.034 & -0.048 \\ (2.14) & (1.98) & (2.46)\end{array}$

Change in Top marginal tax rate (EFW Rating) from 1985 to 1990

Change in Top marginal tax rate (EFW Rating) from 1990 to 1995

Adjusted R-Squared

Number of Observations

$\begin{array}{lll}0.177 & 0.177 & 0.241 \\ (2.03) & (2.02) & (2.53) \\ & & \\ 0.239 & 0.245 & 0.304 \\ (3.03) & (2.91) & (3.35)\end{array}$

$\begin{array}{rrrrrr}40.0 & 39.1 & 40.1 & 43.1 & 42.4 & 43.7 \\ 77 & 77 & 77 & 77 & 77 & 77\end{array}$


Table 8: The Distribution of Household Income in the United States, 1970-2001

\begin{tabular}{|c|c|c|c|c|}
\hline & $\begin{array}{r}\text { Income } \\
\text { Share of } \\
\text { the }\end{array}$ & $\begin{array}{r}\text { Income } \\
\text { Share of } \\
\text { he Middle }\end{array}$ & $\begin{array}{l}\text { Income } \\
\text { Share of }\end{array}$ & $\begin{array}{l}\text { Income } \\
\text { Share of }\end{array}$ \\
\hline Before Taxes & $\begin{array}{l}\text { Bottom } \\
\text { Quintile }\end{array}$ & $\begin{array}{r}\text { Three } \\
\text { Quintiles }\end{array}$ & $\begin{array}{l}\text { the Top } \\
\text { Quintile }\end{array}$ & $\begin{array}{r}\text { the Top } \\
5 \% \\
\end{array}$ \\
\hline 1970 & 4.1 & 52.7 & 43.3 & 16.6 \\
\hline 1980 & 4.3 & 52.1 & 43.7 & 15.8 \\
\hline 1990 & 3.9 & 49.5 & 46.6 & 18.6 \\
\hline 2001 & 3.5 & 46.3 & 50.1 & 22.4 \\
\hline \multicolumn{5}{|l|}{ After Taxes* } \\
\hline 1980 & 4.9 & 54.6 & 40.6 & 14.1 \\
\hline 1990 & 4.5 & 52.0 & 43.5 & 16.5 \\
\hline 2001 & 4.4 & 50.7 & 44.9 & 18.2 \\
\hline
\end{tabular}

After Taxes \& Transfers*

$\begin{array}{llll}1980 & 5.6 & 54.0 & 40.3 \\ 1990 & 5.2 & 51.5 & 43.3 \\ 2001 & 4.7 & 48.7 & 46.5\end{array}$

\section{Sources:}

http://www.census.gov/hhes/income/histinc/h02.html http://www.census.gov/hhes/income/histinc/rdi3.html http://www.census.gov/hhes/income/histinc/rdi7.html

${ }^{*}$ Comparable data after taxes and after taxes and transfers were unavailable for 1970. 
Table 9: Top Marginal Tax Rates and the Distribution of Income:

Persistenltly Low Versus Persistenly High Top Marginal Tax Rates During the 1990s

\begin{tabular}{|c|c|c|c|c|c|c|c|c|c|}
\hline $\begin{array}{l}\text { Low Tax } \\
\text { Countries }\end{array}$ & $\begin{array}{r}\text { Top } \\
\text { Marginal }\end{array}$ & $\begin{array}{r}\text { Top } \\
\text { Marginal }\end{array}$ & $\begin{array}{r}\text { Income } \\
\text { Share of the } \\
\text { Bottom }\end{array}$ & $\begin{array}{l}\text { Income } \\
\text { Share of the }\end{array}$ & & $\begin{array}{l}\text { Income Share } \\
\text { of the Bottom }\end{array}$ & $\begin{array}{r}\text { Income Share } \\
\text { of the Top }\end{array}$ & & $\begin{array}{l}\text { Is Income } \\
\text { Inequality }\end{array}$ \\
\hline $\begin{array}{l}\text { During the } \\
1990 \mathrm{~s}\end{array}$ & $\begin{array}{r}\text { Tax Rate, } \\
1980\end{array}$ & $\begin{array}{r}\text { Tax Rate, } \\
1995 \\
\end{array}$ & $\begin{array}{r}\text { Quintile, } \\
\text { 1980s* }\end{array}$ & $\begin{array}{r}\text { Top Quintile, } \\
1980 \mathrm{~s}^{*}\end{array}$ & Year & $\begin{array}{r}\text { Quintile,1990s- } \\
2000 s^{\star *}\end{array}$ & $\begin{array}{r}\text { Quintile,1990s- } \\
2000 s^{* *}\end{array}$ & Year & $\begin{array}{l}\text { Increasing or } \\
\text { Decreasing?* }^{*}\end{array}$ \\
\hline Bangladesh & 60 & 40 & 7.2 & 43.4 & 1983 & 9.0 & 44.5 & 2000 & No Change \\
\hline Costa Rica & 50 & 25 & 4.5 & 51.8 & 1983 & 4.2 & 51.5 & 2000 & No Change \\
\hline Guatemala & 40 & 25 & 2.7 & 62.1 & 1987 & 2.6 & 64.1 & 2000 & Increasing \\
\hline Hong Kong & 15 & 20 & 6.2 & 46.5 & 1980 & 5.3 & 50.7 & 1996 & Increasing \\
\hline Indonesia & 50 & 30 & 7.3 & 42.3 & 1980 & 8.4 & 43.3 & 2002 & No Change \\
\hline New Zealand & 62 & 33 & 6.0 & 40.6 & 1980 & 6.4 & 43.8 & 1997 & Increasing \\
\hline Philippines & 70 & 35 & 5.2 & 52.1 & 1985 & 5.4 & 52.3 & 2000 & No Change \\
\hline Singapore & 55 & 30 & 6.5 & 46.6 & 1980 & 5.0 & 49.0 & 1998 & Increasing \\
\hline United Kingdom & 83 & 40 & 5.5 & 41.4 & 1986 & 6.1 & 44.0 & 1999 & Increasing \\
\hline
\end{tabular}

\section{High Tax}

Countries

During the

1990s

\begin{tabular}{llllllllrr}
\cline { 1 - 2 } & 62 & 50 & 6.6 & 38.6 & 1981 & 8.1 & 38.5 & 1997 & No Change \\
Belgium & 76 & 61 & 8.6 & 34.7 & 1985 & 8.3 & 37.3 & 1996 & Increasing \\
Denmark & 66 & 64 & 6.7 & 37.2 & 1981 & 8.3 & 35.8 & 1997 & Decreasing \\
Finland & 68 & 57 & 6.8 & 36.9 & 1987 & 9.6 & 36.7 & 2000 & Decreasing \\
France & 60 & 51 & 6.6 & 42.0 & 1984 & 7.2 & 40.2 & 1995 & Decreasing \\
Germany & 65 & 57 & 6.8 & 37.4 & 1981 & 8.5 & 36.9 & 2000 & Decreasing \\
Japan & 75 & 65 & 6.3 & 39.6 & 1980 & 10.6 & 35.7 & 1993 & Decreasing \\
Netherlands & 72 & 60 & 6.1 & 39.8 & 1983 & 7.3 & 40.1 & 1994 & No Change \\
Sweden & 87 & 50 & 9.0 & 35.3 & 1981 & 9.1 & 36.6 & 2000 & No Change
\end{tabular}

Sources:

1980s income distribution data are from Deininger and Squire Data Set, A New Data Set Measuring Income Inequality, http://www.worldbank.org/research/growth/dddeisqu.htm 1990s income distribution data are from the World Bank,World Development Indicators 2004

*The 'No Change' label indicates that the average difference between the two periods for the top and bottom quintiles was less than one percentage point. 
Table 10: Marginal Tax Rates and Incomes Taxes Paid by Various Income Groups in the U.S., 1963-2001

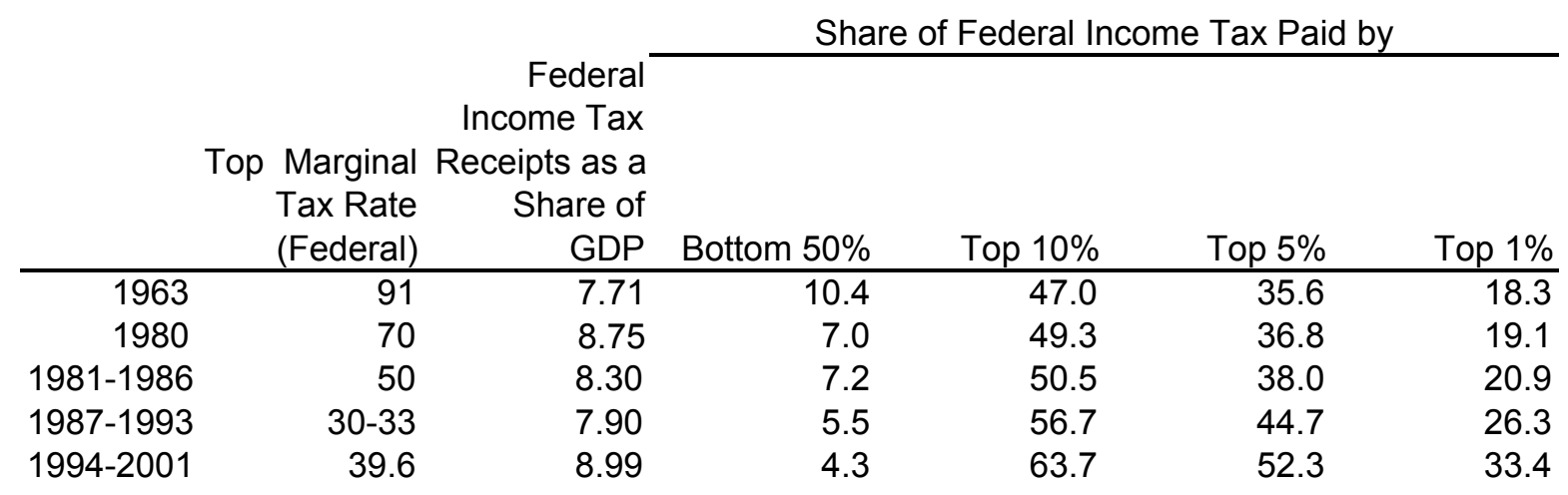

\section{Sources:}

Internal Revenue Service (available online at the Tax Foundation's website: http://www.taxfoundation.org/prtop Economic Report of the President, 2005. Table B-80 
Table 11: Marginal Tax Rates and Incomes Taxes Paid by Various Income Groups in New Zealand and the United Kingdom

\begin{tabular}{r|r|rrrr} 
& \multicolumn{5}{|c}{ Share of Income Tax Paid By: } \\
New Zealand & $\begin{array}{r}\text { Top Margina } \\
\text { Tax Rate }\end{array}$ & Bottom 50\% & Top 10\% & Top 5\% & Top 1\% \\
\hline 1981 & 62 & 12.4 & 38.0 & 25.1 & 9.5 \\
1991 & 33 & 13.6 & 37.3 & 25.3 & 10.6 \\
1998 & 39 & 12.2 & 41.3 & 29.0 & 12.8 \\
& & & & & \\
United Kingdom & & & & & 11.0 \\
1980 & 43 & 18.0 & 35.0 & n.a. & 15.0 \\
1990 & 40 & 15.0 & 42.0 & n.a. & 20.0
\end{tabular}

Sources:

New Zealand, Inland Revenue memo to New Zealand Business Roundtable.

Adam Smith Institute 
Table A1: Top Marginal Tax Rates, Income Thresholds, and EFW Ratings

\begin{tabular}{|c|c|c|cc|}
\hline $\begin{array}{c}\text { Top Marginal } \\
\text { Tax Rate }\end{array}$ & Less than $\$ 25,000$ & 25,000 to 50,000 & 50,000 to 150,000 & More than $\$ 150,000$ \\
\hline $\begin{array}{c}\text { Less than } 20 \% \\
21 \text { to } 25\end{array}$ & 10 & 10 & 10 & 10 \\
26 to 30 & 9 & 9 & 10 & 10 \\
31 to 35 & 8 & 8 & 9 & 9 \\
36 to 40 & 7 & 7 & 8 & 9 \\
41 to 45 & 5 & 5 & 7 & 8 \\
46 to 50 & 4 & 4 & 6 & 5 \\
51 to 55 & 3 & 3 & 5 & 4 \\
56 to 60 & 2 & 2 & 4 & 3 \\
61 tp 65 & 1 & 1 & 3 & 2 \\
66 to 70 & 0 & 0 & 2 & 1 \\
More than $70 \%$ & 0 & 0 & 1 & 0 \\
\hline
\end{tabular}

Note: Countries with higher marginal tax rates that take effect at lower income thresholds received lower ratings based on the matrix found a

Source:

James Gwartney and Robert Lawson. Economic Freedom of the World, 2004 Annual Report (Vancou 
Table A2: Top Marginal Tax Rates on Personal Income (excluding payroll taxes) and EFW Ratings, 1980-2002

\begin{tabular}{|c|c|c|c|c|c|c|c|c|c|c|c|c|c|c|}
\hline \multirow[b]{2}{*}{ Countries } & 19 & & 19 & & $19 s$ & & 19 & & $20 c$ & & 200 & & Average 1 & $1980-2000$ \\
\hline & Tax Rate & Rating & Tax Rat & Rating & Tax Rate & Rating & Tax Rate & Rating & Tax Rate & Rating & Tax Rate & Rating & Tax Rate & Rating \\
\hline Argentina & 45 & 6 & 62 & 2 & 35 & 7 & 30 & 9 & 35 & 8 & 35 & 7 & 40.3 & 6.5 \\
\hline Australia & 62 & 2 & 60 & 2 & 49 & 3 & 47 & 4 & 47 & 3 & 47 & 3 & 52.0 & 2.8 \\
\hline Austria & 62 & 2 & 62 & 2 & 50 & 4 & 50 & 4 & 50 & 4 & 50 & 4 & 54.0 & 3.3 \\
\hline Bangladesh & 60 & 1 & 60 & 1 & 25 & 9 & 25 & 9 & 25 & 9 & 25 & 9 & 36.7 & 6.3 \\
\hline Barbados & 60 & 1 & 60 & 1 & 50 & 4 & 40 & 5 & 40 & 5 & 40 & 5 & 48.3 & 3.5 \\
\hline Belgium & 76 & 0 & 76 & 0 & 58 & 2 & 61 & 1 & 60 & 2 & 52 & 2 & 63.9 & 1.2 \\
\hline Belize & & & 50 & 4 & 45 & 4 & 45 & 5 & 45 & 5 & 45 & 5 & 46.0 & 4.6 \\
\hline Bolivia & 48 & 3 & 30 & 8 & 10 & 10 & 13 & 10 & 13 & 10 & 13 & 10 & 21.2 & 8.5 \\
\hline Botswana & 75 & 0 & 60 & 2 & 50 & 3 & 35 & 7 & 25 & 9 & 25 & 9 & 45.0 & 5.0 \\
\hline Brazil & 55 & 4 & 60 & 1 & 25 & 9 & 35 & 8 & 28 & 8 & 28 & 8 & 38.4 & 6.3 \\
\hline Cameroon & & & 60 & 2 & 60 & 1 & 66 & 0 & 69 & 0 & 65 & 0 & 64.0 & 0.6 \\
\hline Canada & 64 & 2 & 57 & 2 & 49 & 4 & 49 & 4 & 48 & 3 & 34 & 5 & 50.1 & 3.3 \\
\hline Chile & 58 & 2 & 56 & 2 & 50 & 4 & 45 & 6 & 45 & 5 & 40 & 5 & 49.0 & 4.0 \\
\hline China & & & 45 & 6 & 45 & 5 & 45 & 6 & 45 & 6 & 45 & 4 & 45.0 & 5.4 \\
\hline Colombia & 56 & 2 & 49 & 5 & 30 & 8 & 30 & 8 & 35 & 7 & 35 & 7 & 39.2 & 6.2 \\
\hline Congo, Dem. R. & 60 & 1 & 60 & 1 & 60 & 1 & 60 & 1 & 60 & 1 & 50 & 3 & 58.3 & 1.3 \\
\hline Costa Rica & 50 & 5 & 50 & 3 & 25 & 9 & 25 & 9 & 25 & 9 & 30 & 8 & 34.2 & 7.2 \\
\hline Cote d'Ivoire & 45 & 5 & 45 & 5 & 45 & 4 & 49 & 3 & 49 & 3 & 49 & 3 & 47.0 & 3.8 \\
\hline Cyprus & 60 & 1 & 60 & 1 & 60 & 1 & 40 & 5 & 40 & 5 & 30 & 8 & 48.3 & 3.5 \\
\hline Denmark & 66 & 0 & 73 & 0 & 68 & 0 & 64 & 1 & 59 & 2 & 59 & 1 & 64.8 & 0.7 \\
\hline Dominican Rep. & 73 & 0 & 73 & 0 & 73 & 0 & 25 & 9 & 25 & 9 & 25 & 9 & 49.0 & 4.5 \\
\hline Ecuador & 50 & 5 & 58 & 2 & 25 & 9 & 25 & 9 & 25 & 9 & 25 & 9 & 34.7 & 7.2 \\
\hline Egypt & 80 & 0 & 65 & 2 & 65 & 2 & 50 & 3 & 34 & 7 & 34 & 7 & 54.7 & 3.5 \\
\hline El Salvador & 60 & 3 & 48 & 3 & 60 & 2 & 30 & 8 & 30 & 8 & 30 & 8 & 43.0 & 5.3 \\
\hline Fiji & 53 & 2 & 50 & 3 & 50 & 3 & 35 & 7 & 34 & 7 & 32 & 7 & 42.3 & 4.8 \\
\hline Finland & 68 & 1 & 67 & 1 & 60 & 2 & 57 & 2 & 54 & 3 & 54 & 3 & 60.0 & 2.0 \\
\hline France & 60 & 3 & 65 & 1 & 53 & 3 & 51 & 4 & 54 & 2 & 53 & 2 & 56.0 & 2.5 \\
\hline Germany & 65 & 2 & 65 & 1 & 53 & 4 & 57 & 3 & 56 & 3 & 51 & 4 & 57.8 & 2.8 \\
\hline Ghana & 60 & 1 & 60 & 1 & 55 & 2 & 35 & 7 & 30 & 8 & 30 & 8 & 45.0 & 4.5 \\
\hline Greece & 60 & 3 & 63 & 1 & 50 & 4 & 45 & 5 & 43 & 5 & 40 & 5 & 50.1 & 3.8 \\
\hline Guatemala & 40 & 8 & 48 & 5 & 34 & 7 & 25 & 9 & 31 & 7 & 31 & 7 & 34.8 & 7.2 \\
\hline Honduras & 40 & 8 & 46 & 5 & 46 & 5 & 40 & 7 & 25 & 9 & 25 & 9 & 37.0 & 7.2 \\
\hline Hong Kong & 15 & 10 & 25 & 9 & 25 & 9 & 20 & 10 & 17 & 10 & 17 & 10 & 19.8 & 9.7 \\
\hline Iceland & 63 & 0 & 56 & 1 & 40 & 5 & 47 & 4 & 45 & 6 & 46 & 5 & 49.5 & 3.5 \\
\hline India & 60 & 1 & 62 & 0 & 53 & 2 & 40 & 5 & 30 & 8 & 32 & 7 & 46.2 & 3.8 \\
\hline Indonesia & 50 & 3 & 35 & 7 & 35 & 7 & 30 & 8 & 35 & 7 & 35 & 7 & 36.7 & 6.5 \\
\hline Iran & & & 90 & 0 & 75 & 0 & 54 & 4 & 54 & 2 & 35 & 8 & 61.6 & 2.8 \\
\hline Ireland & 60 & 1 & 65 & 0 & 56 & 1 & 48 & 3 & 42 & 5 & 42 & 5 & 52.2 & 2.5 \\
\hline Israel & 66 & 1 & 60 & 3 & 48 & 5 & 50 & 4 & 50 & 4 & 50 & 4 & 54.0 & 3.5 \\
\hline Italy & 72 & 0 & 81 & 0 & 66 & 1 & 67 & 1 & 51 & 3 & 47 & 4 & 64.0 & 1.5 \\
\hline Jamaica & 80 & 0 & 58 & 1 & 33 & 7 & 25 & 9 & 25 & 9 & 25 & 9 & 41.0 & 5.8 \\
\hline Japan & 75 & 0 & 70 & 1 & 65 & 2 & 65 & 2 & 50 & 5 & 50 & 5 & 62.5 & 2.5 \\
\hline Kenya & 65 & 1 & 65 & 0 & 50 & 3 & 50 & 3 & 32 & 7 & 30 & 8 & 48.7 & 3.7 \\
\hline Malawi & 45 & 4 & 50 & 3 & 50 & 3 & 35 & 7 & 38 & 5 & 38 & 5 & 42.7 & 4.5 \\
\hline Malaysia & 60 & 2 & 45 & 6 & 45 & 6 & 32 & 7 & 29 & 8 & 28 & 8 & 39.8 & 6.2 \\
\hline Malta & 65 & 0 & 65 & 0 & 65 & 0 & 35 & 7 & 35 & 7 & 35 & 7 & 50.0 & 3.5 \\
\hline Mauritius & 50 & 3 & 35 & 7 & 35 & 7 & 30 & 8 & 25 & 9 & 25 & 9 & 33.3 & 7.2 \\
\hline Mexico & 55 & 4 & 55 & 4 & 40 & 7 & 35 & 7 & 40 & 7 & 35 & 7 & 43.3 & 6.0 \\
\hline Morocco & 64 & 2 & 87 & 0 & 87 & 0 & 46 & 3 & 44 & 4 & 44 & 4 & 62.0 & 2.2 \\
\hline Netherlands & 72 & 0 & 72 & 0 & 60 & 3 & 60 & 2 & 52 & 3 & 52 & 2 & 61.3 & 1.7 \\
\hline New Zealand & 62 & 2 & 66 & 0 & 33 & 7 & 33 & 7 & 39 & 5 & 39 & 5 & 45.3 & 4.3 \\
\hline Nigeria & 70 & 0 & 55 & 3 & 55 & 2 & 35 & 7 & 25 & 9 & 25 & 9 & 44.2 & 5.0 \\
\hline Norway & 75 & 0 & 64 & 1 & 51 & 3 & 42 & 5 & 48 & 5 & 48 & 5 & 54.6 & 3.2 \\
\hline Pakistan & 55 & 2 & 60 & 1 & 50 & 3 & 45 & 4 & 35 & 7 & 35 & 7 & 46.7 & 4.0 \\
\hline Panama & 56 & 3 & 56 & 3 & 56 & 3 & 30 & 9 & 31 & 8 & 31 & 8 & 43.4 & 5.7 \\
\hline Paraguay & & & 30 & 8 & 30 & 8 & 0 & 10 & 0 & 10 & 0 & 10 & 12.0 & 9.2 \\
\hline Peru & 65 & 2 & 65 & 0 & 45 & 4 & 30 & 8 & 20 & 10 & 30 & 8 & 42.5 & 5.3 \\
\hline Philippines & 70 & 1 & 60 & 1 & 35 & 7 & 35 & 7 & 32 & 7 & 32 & 7 & 44.0 & 5.0 \\
\hline Portugal & 84 & 0 & 69 & 0 & 40 & 5 & 40 & 5 & 40 & 6 & 40 & 6 & 52.2 & 3.7 \\
\hline Senegal & & & 65 & 1 & 48 & 4 & 64 & 0 & 50 & 3 & 50 & 3 & 55.4 & 2.2 \\
\hline Singapore & 55 & 4 & 40 & 8 & 33 & 9 & 30 & 9 & 28 & 9 & 22 & 10 & 34.7 & 8.2 \\
\hline South Africa & 60 & 2 & 50 & 4 & 45 & 5 & 43 & 4 & 45 & 4 & 40 & 5 & 47.2 & 4.0 \\
\hline South Korea & 89 & 0 & 65 & 2 & 64 & 2 & 48 & 5 & 44 & 5 & 40 & 6 & 58.3 & 3.3 \\
\hline Spain & 66 & 1 & 66 & 1 & 56 & 3 & 56 & 2 & 48 & 4 & 40 & 5 & 55.3 & 2.7 \\
\hline Sweden & 87 & 0 & 80 & 0 & 65 & 0 & 50 & 3 & 55 & 2 & 56 & 3 & 65.4 & 1.3 \\
\hline Switzerland & 37 & 7 & 40 & 7 & 38 & 8 & 37 & 8 & 36 & 9 & 36 & 9 & 37.3 & 8.0 \\
\hline Taiwan & 60 & 3 & 60 & 3 & 50 & 5 & 40 & 7 & 40 & 7 & 40 & 7 & 48.3 & 5.3 \\
\hline Tanzania & & & 95 & 0 & 50 & 3 & 30 & 8 & 31 & 7 & 31 & 7 & 47.4 & 5.0 \\
\hline Thailand & 60 & 3 & 65 & 2 & 55 & 4 & 37 & 7 & 37 & 7 & 37 & 6 & 48.5 & 4.8 \\
\hline Trinidad \& Tob. & & & 50 & 4 & 35 & 7 & 38 & 5 & 35 & 7 & 30 & 8 & 37.6 & 6.2 \\
\hline Turkey & 75 & 0 & 63 & 2 & 50 & 4 & 55 & 4 & 45 & 6 & 40 & 6 & 54.7 & 3.7 \\
\hline Uganda & & & 70 & 0 & 50 & 3 & 30 & 8 & 30 & 8 & 30 & 8 & 42.0 & 5.4 \\
\hline United Kingdom & 83 & 0 & 60 & 2 & 40 & 5 & 40 & 5 & 40 & 6 & 40 & 6 & 50.5 & 4.0 \\
\hline United States & 73 & 0 & 55 & 4 & 38 & 7 & 43 & 7 & 43 & 7 & 40 & 8 & 48.7 & 5.5 \\
\hline Venezuela & 45 & 7 & 45 & 7 & 45 & 7 & 34 & 7 & 35 & 8 & 34 & 7 & 39.7 & 7.2 \\
\hline Zambia & 70 & 0 & 80 & 0 & 75 & 0 & 35 & 7 & 30 & 8 & 30 & 8 & 53.3 & 3.8 \\
\hline Zimbabwe & 45 & 5 & 63 & 0 & 60 & 1 & 45 & 4 & 53 & 2 & 46 & 3 & 52.0 & 2.5 \\
\hline Average & 61.3 & 2.2 & 59.2 & 2.4 & 48.5 & 4.2 & 40.8 & 5.6 & 38.6 & 6.1 & 37.1 & 6.2 & 47.3 & 4.5 \\
\hline Median & 60 & 2 & 60 & 2 & 50 & 4 & 40 & 6 & 39 & 7 & 35 & 7 & 48 & 4 \\
\hline Number & 68 & 68 & 77 & 77 & 77 & 77 & 77 & 77 & 77 & 77 & 77 & 77 & 77 & 77 \\
\hline
\end{tabular}

Source:

James Gwartney and Robert LawsonEconomic Freedom of the World, 2004 Annual Report (Vancouver, BC: Fraser Institute, 2004). 
Table A3: Top Marginal Tax Rates on Personal Income (including payroll taxes): 1990, 1995, 2000

\begin{tabular}{|c|c|c|c|}
\hline Countries & 1990 & 1995 & 2000 \\
\hline Argentina & 57 & 40 & 40 \\
\hline Australia & 49 & 48 & 49 \\
\hline Austria & 62 & 66 & 66 \\
\hline Bangladesh & 25 & 25 & 25 \\
\hline Barbados & 54 & 53 & 53 \\
\hline Belgium & 70 & 61 & 71 \\
\hline \multicolumn{4}{|l|}{ Belize } \\
\hline Bolivia & 16 & 22 & \\
\hline Botswana & 50 & 35 & 25 \\
\hline Brazil & 53 & 60 & 55 \\
\hline Cameroon & 63 & 69 & 68 \\
\hline Canada & 49 & 49 & 48 \\
\hline Chile & 50 & 45 & 45 \\
\hline \multicolumn{4}{|l|}{ China } \\
\hline Colombia & 30 & 30 & 43 \\
\hline Congo, Dem. R & 60 & 63 & 63 \\
\hline Costa Rica & 33 & 33 & 39 \\
\hline \multicolumn{4}{|l|}{ Cote d'Ivoire } \\
\hline Cyprus & 62 & 48 & 48 \\
\hline Denmark & 69 & 67 & 63 \\
\hline Dominican Rep & 73 & 25 & 25 \\
\hline Ecuador & 32 & 32 & 32 \\
\hline \multicolumn{4}{|l|}{ Egypt } \\
\hline \multicolumn{4}{|l|}{ El Salvador } \\
\hline Fiji & 50 & 35 & 34 \\
\hline Finland & 65 & 63 & 62 \\
\hline France & 61 & 60 & 64 \\
\hline Germany & 53 & 57 & 56 \\
\hline Ghana & 62 & 45 & 41 \\
\hline Greece & 50 & 45 & 50 \\
\hline Guatemala & 37 & 28 & 34 \\
\hline Honduras & 46 & 40 & 25 \\
\hline Hong Kong & 25 & 20 & 17 \\
\hline Iceland & & & 48 \\
\hline India & 53 & 40 & 30 \\
\hline Indonesia & 35 & 40 & 40 \\
\hline Iran & 75 & 54 & 57 \\
\hline Ireland & 57 & 51 & 42 \\
\hline Israel & 64 & 66 & 62 \\
\hline Italy & 66 & 67 & 52 \\
\hline Jamaica & 37 & 31 & 31 \\
\hline Japan & 69 & 69 & 50 \\
\hline Kenya & 50 & 50 & 32 \\
\hline Malawi & 50 & 35 & 38 \\
\hline Malaysia & 45 & 32 & 29 \\
\hline Malta & 65 & 35 & 35 \\
\hline Mauritius & 35 & 32 & 33 \\
\hline Mexico & & & 47 \\
\hline \multicolumn{4}{|l|}{ Morocco } \\
\hline Netherlands & 63 & 63 & 54 \\
\hline New Zealand & 33 & 33 & 40 \\
\hline Nigeria & & & 25 \\
\hline Norway & 64 & 56 & 64 \\
\hline Pakistan & 50 & 45 & 35 \\
\hline Panama & 64 & 38 & 38 \\
\hline \multicolumn{4}{|l|}{ Paraguay } \\
\hline Peru & 48 & 39 & 41 \\
\hline Philippines & 35 & 35 & 32 \\
\hline Portugal & 57 & 57 & 57 \\
\hline Senegal & 48 & 64 & 50 \\
\hline Singapore & 33 & 30 & 28 \\
\hline South Africa & 45 & 43 & 45 \\
\hline South Korea & 66 & 48 & 44 \\
\hline Spain & 56 & 56 & 48 \\
\hline Sweden & 83 & 70 & 72 \\
\hline Switzerland & 41 & 40 & 44 \\
\hline Taiwan & 50 & 40 & 40 \\
\hline Tanzania & 57 & 45 & 46 \\
\hline Thailand & 55 & 37 & 37 \\
\hline Trinidad \& Tob. & 35 & 38 & 35 \\
\hline Turkey & 57 & 55 & 46 \\
\hline Uganda & 59 & 41 & 40 \\
\hline United Kingdor & 40 & 40 & 40 \\
\hline United States & 41 & 46 & 46 \\
\hline Venezuela & 45 & 34 & 35 \\
\hline Zambia & & & \\
\hline Zimbabwe & 60 & 45 & 53 \\
\hline Average & 51.4 & 45.5 & 44.1 \\
\hline Median & 52 & 45 & 43 \\
\hline Number & 66 & 66 & 68 \\
\hline
\end{tabular}

Source:

James Gwartney and Robert LawsonEconomic Freedom of the World, 2004 Annual Report (Vancouver, BC: Fraser Institute, 2004). 